6-21-2004

\title{
Bridgehead-methyl Analog of SC-53116 as a 5-HT4 Agonist
}

Daniel Becker

Loyola University Chicago, dbecke3@luc.edu

Daniel L. Flynn

Clara I. Villamil

Follow this and additional works at: https://ecommons.luc.edu/chemistry_facpubs

Part of the Chemistry Commons

\section{Author Manuscript}

This is a pre-publication author manuscript of the final, published article.

\section{Recommended Citation}

Becker, Daniel; Flynn, Daniel L.; and Villamil, Clara I.. Bridgehead-methyl Analog of SC-53116 as a 5-HT4 Agonist. Bioorganic \& Medicinal Chemistry Letters, 14, 12: , 2004. Retrieved from Loyola eCommons, Chemistry: Faculty Publications and Other Works, http://dx.doi.org/10.1016/j.bmcl.2004.04.021

This Article is brought to you for free and open access by the Faculty Publications and Other Works by Department at Loyola eCommons. It has been accepted for inclusion in Chemistry: Faculty Publications and Other Works by an authorized administrator of Loyola eCommons. For more information, please contact ecommons@luc.edu. c) (i) $(9$

This work is licensed under a Creative Commons Attribution-Noncommercial-No Derivative Works 3.0 License. (c) 2004 Elsevier 


\section{Bridgehead-Methyl Analog of SC-53116 as a 5-HT4 Agonist}

Daniel P. Becker*, Daniel L. Flynn, and Clara I. Villamil

Department of Medicinal Chemistry, Pfizer Research \& Development, 4901 Searle Parkway, Skokie, IL 60077 Pyrrolizidine ( \pm )-2, the bridgehead-methyl analog of SC-53116, was prepared and evaluated for 5-HT 4 agonism activity in the rat tunica muscularis (TMM) mucosae assay. Compound ( \pm )-2 has an $\mathrm{EC}_{50}$ of $449 \mathrm{nM}$ in the TMM assay, as compared to $23 \mathrm{nM}$ for SC-53116, and $66 \mathrm{nM}$ for the racemate of SC-53116.

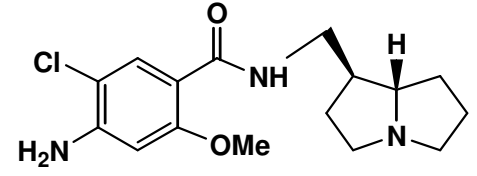

SC-53116<smiles>CC12CCC(=O)N1CCO2</smiles>

(士)-5

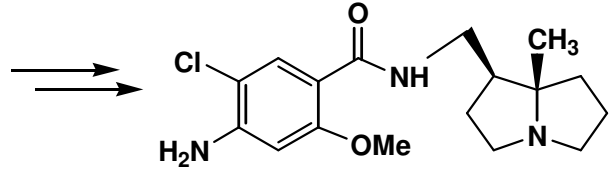

(土)-2 


\title{
Bridgehead-Methyl Analog of SC-53116 as a 5-HT4 Agonist
}

\author{
Daniel P. Becker*, Daniel L. Flynn ${ }^{\S}$, and Clara I. Villamil ${ }^{\ddagger}$ \\ Department of Medicinal Chemistry, Pfizer Research \& Development, 4901 Searle \\ Parkway, Skokie, IL 60077 \\ "To whom correspondence should be addressed. Current address: Department of Chemistry, Loyola \\ University, 6525 North Sheridan Road, Chicago, IL 60626, dbecke3@luc.edu \\ ${ }^{\S}$ Current address: Deciphera Pharmaceuticals Inc., 1505 Wakarusa Drive, Lawrence, KS 66047 USA \\ ${ }^{\ddagger}$ Current address: Abbott Labs, 100 Abbott Park Road, Abbott Park, IL 60064-6099
}

Abstract-Pyrrolizidine benzamide ( \pm )-2, the bridgehead-methyl analog of SC-53116, was prepared and evaluated for $5-\mathrm{HT}_{4}$ agonism activity in the rat tunica muscularis (TMM) mucosae assay. Compound ( \pm )-2 has an $\mathrm{EC}_{50}$ of $449 \mathrm{nM}$ in the TMM assay, as compared to $23 \mathrm{nM}$ for SC-53116, and $66 \mathrm{nM}$ for the racemate of SC-53116.

We have previously reported our discovery of SC-53116, which was the first selective agonist at the 5- $\mathrm{HT}_{4}$ receptor. ${ }^{1}$ SC-53116 has an $\mathrm{ED}_{50}$ of $23 \mathrm{nM}$ in the tunica muscularis mucosae assay of Craig and Clarke, ${ }^{2}$ and is selective versus other monoamine receptors with a $\mathrm{K}_{\mathrm{i}}$ of $152 \mathrm{nM}$ at the $5-\mathrm{HT}_{3}$ receptor and $\mathrm{K}_{\mathrm{i}}$ 's of $>10,000 \mathrm{nM}$ at the $5-\mathrm{HT}_{1}, 5-\mathrm{HT}_{2}, \mathrm{D}_{1}, \mathrm{D}_{2}$, $\alpha_{1}, \alpha_{2}$ and $\beta$-receptors. The 5-HT $\mathrm{H}_{4}$ receptor was discovered by Clark $^{2}$ and Bockaert ${ }^{3}$ in the brain and gut, respectively, and is expressed in a wide variety of tissues including brain, heart, bladder, gut and kidney. ${ }^{4}$ Selective ligands for the receptor show promise in the treatment of diseases including the irritable bowel syndrome, atrial arrhythmia, urinary incontinence, and gastrointestinal motility disorders. An excellent review of the 5-HT 4 receptor and key ligands was recently published. ${ }^{5}$

We have been interested in pursuing $5-\mathrm{HT}_{4}$ agonists as gastrointestinal prokinetic agents. Our efforts in this area ${ }^{6}$ have also prompted us to develop several azatricyclic benzamides ${ }^{7}$ that are potent 5- $\mathrm{HT}_{4}$ agonists and 5- $\mathrm{HT}_{3}$ antagonists, particularly $\mathbf{S C - 5 2 4 9 1},{ }^{8}$ in addition to the pyrrolizidine SC-53116.

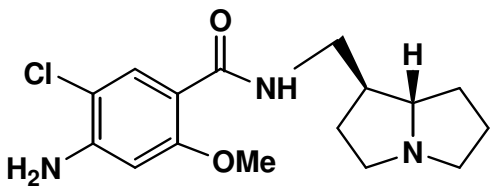

SC-53116

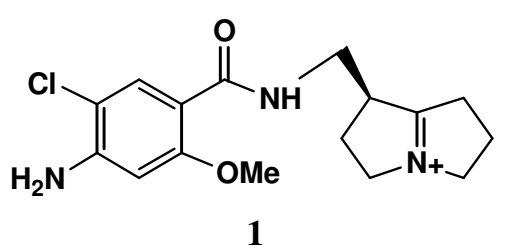<smiles>COc1cc(N)c(Cl)cc1C(=O)NC1C2CN3CC1C3(C)C2</smiles>

SC-52491

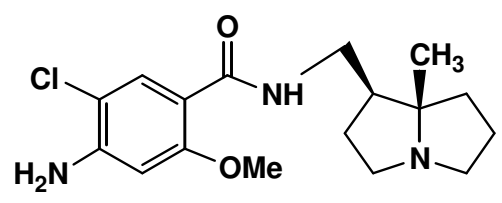

$( \pm)-2$ 
SC-53116 was a clinical candidate but was halted when it was observed to be positive in the Ames assay when tested with S9 activation. ${ }^{9}$ We hypothesized that this toxicity was due to oxidation of the pyrrolizidine moiety to the bicyclic iminium ion $\mathbf{1}$, which can then function as an alkylating agent. To avoid this liability, we targeted the bridgehead-methyl SC-53116 analog $( \pm)-2$, as the methyl group would block metabolism to the iminium species. We targeted the racemate initially to test the concept and ensure that sufficient potency is maintained with the additional methyl group.

We employed general methodology reported by Meyers ${ }^{10}$ for introduction of the requisite quaternary carbon at the pyrrolizidinone bridgehead position. As outlined in Scheme 1, ketoester 3 was heated under reflux with ethanolamine to afford $( \pm)-4^{11}$ in $53 \%$ yield. The bicyclic lactam $( \pm)-4$ was treated with t-butyldimethylsilyl methyl acetate ketal ${ }^{12}$ in $2 \mathrm{M}$ lithium perchlorate ether ${ }^{13}$ to afford lactam $( \pm)-5$ in $30 \%$ yield. Attempts with titanium tetrachloride in methylene chloride also afforded ( \pm )-5 but in lower yield. The primary alcohol of $( \pm)-5$ was converted to the tosylate in $86 \%$ yield by treating with tosyl chloride in pyridine. Treatment of the tosylate with sodium iodide under Finkelstein conditions afforded the primary iodide $( \pm)-6$.

Scheme 1: Synthesis of ( \pm -2

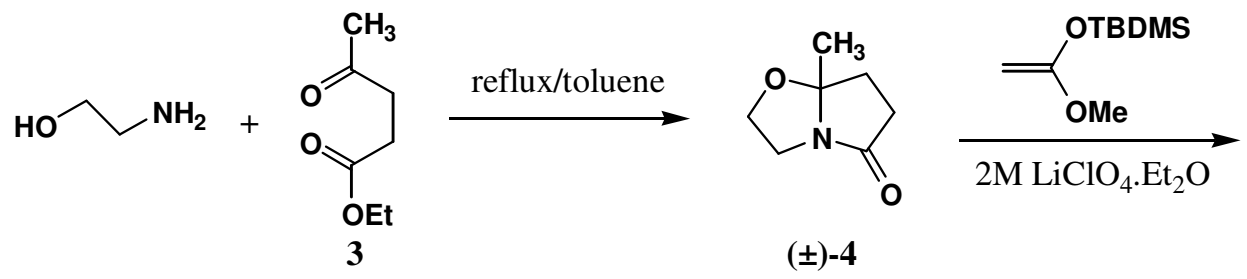<smiles>CC(=O)CC1(C)CCC(=O)N1CCO</smiles>

$( \pm)-5$

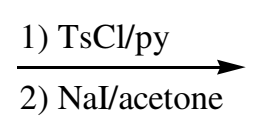

2) NaI/acetone<smiles>CC(=O)CC1(C)CCC(=O)N1CCI</smiles>

$( \pm)-6$
KHMDS/THF<smiles>C1CC1</smiles>

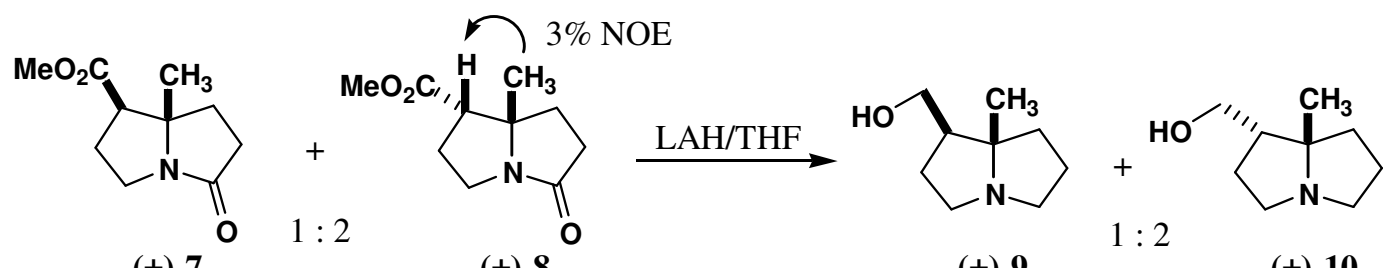

$( \pm)-7$

$( \pm)-8$

$( \pm)-9$

$( \pm)-10$

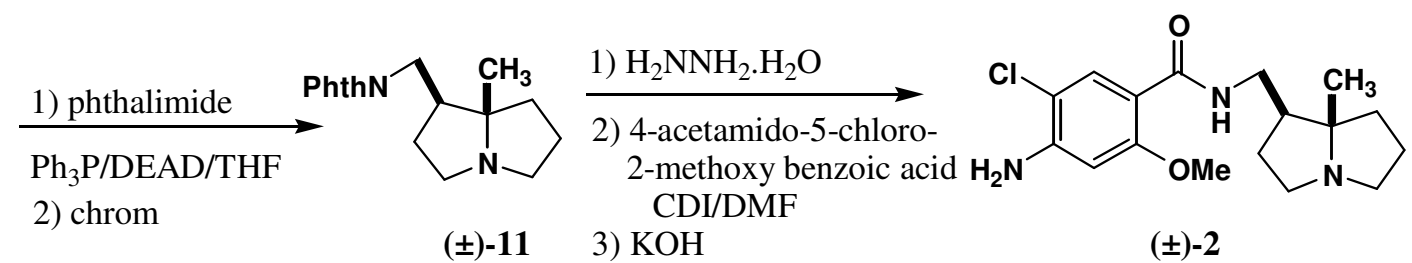

A variety of bases were employed to effect closure of ( \pm )-6, with potassium hexamethyldisilazide giving the best yield of ( \pm -7 7 and ( \pm )-8 in a combined $70 \%$ yield. The 
exo and endo methyl esters were isolated in a 1:2 ratio, with the endo ( \pm )-8 as the main component, as determined by NOE. ${ }^{14}$ Reduction with lithium aluminum hydride gave a mixture of alcohols $( \pm)-9$ and $( \pm)-\mathbf{1 0}$, and this mixture was converted directly to the phthalimides under Mitsunobu conditions, allowing chromatographic isolation of the requisite exo isomer $( \pm)-\mathbf{1 1}$ in $24 \%$ yield. Deprotection of $( \pm)$-11 with hydrazine gave the free amine in quantitative yield which was coupled directly with 5-acetamido-4-chloro-2methoxybenzoic acid utilizing carbonyl diimidazole to afford the desired benzamide. The acetamide was removed with potassium hydroxide in ethanol under reflux to afford the desired benzamide isomer ( \pm )-2 in $66 \%$ yield.

Thus ( \pm )-2, the bridgehead-methyl analog of SC-53116, was tested for agonist activity at the $5-\mathrm{HT}_{4}$ receptor in the rat tunica muscularis mucosae assay. The potency for the compound was good, at $449 \mathrm{nM}( \pm 185)$. However, this was approximately $7 \mathrm{X}$ less potent than SC49518, the racemate of SC-53116, which has an EC50 of $66 \mathrm{nM} \pm 11 \mathrm{nM}$. Due to the loss of potency, the bridgehead methyl analog $( \pm)-2$ was not pursued further. The azatricycle benzamide compounds that we developed ${ }^{7,8}$ are potent, efficacious, and safe, so we turned our attention to those molecules. Specifically, SC-52491 was negative in the Ames assay at the highest concentrations tested, either with or without $\mathrm{S} 9$ activation. ${ }^{15}$

\section{References and Notes}

1. Flynn, D. L.; Zabrowski, D. L.; Becker, D. P.; Nosal, R.; Villamil, C. I.; Gullikson, G. W.; Moummi, Ch. Yang, Dai-C. J. Med. Chem., 1992, 35, 1486.

2. Baxter, G. S.; Craig, D. A.; Clarke, D. E. Naunyn-Schmiedeberg's Arch. Pharmacol. 1991, 343, 439 .

3. Dumuis, A.; Sebbon, M.; Bockaert, J. Naunyn Schmiedebergs Arch. Pharmacol. 1989, $340,403$.

4. (a) Berque-Bestel, I.; Soulier, J.-L.; Giner, M.; Rivail, L.; Langlois, M.; Sicsic, S.; J. Med. Chem. 2003, 46, 2606. (b) Eglen, R. M.; Wong. E. H. F.; Dumuis, A.; Bockaert, J. Trends

Pharmacol. Sci. 1995, 16, 391. (c) Hedge, S.; Eglen, R. FASEB J. 1996, 10, 1398.

5. Langlois, M.; Fischmeister, R. J. Med. Chem. 2003, 46, 319.

6. Becker, D. P.; Goldstin, B.; Gullikson, G. W.; Loeffler, R.; Moormann, A.; Moummi, C.; Nosal, R.; Spangler, D.; Villamil, C. I.; Yang, D.-C.; Zabrowski, D. L.; Flynn, D. L. "Design and Synthesis of Agonists and Antagonists of the Serotonin 5-HT Receptor Subtype", in "Perspectives in Receptor Research", ed. D. Giardina et. al. , Pharmacochemistry Library, Vol. 24, Elsevier Science B. V.: Amsterdam, 1996, pp. 99-120.

7. Becker, D. P.; Nosal, R.; Villamil, C. I.; Gullikson, G.; Moummi, C.; Yang, D.-C. Flynn, D. L. Bioorg. Med. Chem. Lett. 1997, 7, 2149.

8. (a) Becker, D. P.; Husa, R. K.; Moormann, A. E.; Villamil, C. I.; Flynn, D. L. Tetrahedron 1999, 55, 11787. (b) Becker, D. P.; Nosal, R.; Zabrowski, D. L.; Flynn, D. L. Tetrahedron 1997, 53, 1. (c) Flynn, D. L.; Becker, D. P.; Spangler, D. P.; Nosal, R.; Gullikson, G. W.; Moummi, C.; Yang, D.-C. Bioorg. Med. Chem. Lett. 1992, 2, 1613. 9. SC-53116 was tested for mutagenic activity in a GLP study using the Ames Salmonella/microsome assay with five strains of Salmonella typhimurium (TA1535, TA100, TA1538, TA98, and TA97) in the presence and absence of a rat liver homogenate metabolic activation system (S9) over test article concentrations ranging from 7.2 to $3600 \mu \mathrm{g} /$ plate. 
Significant test article-related increases of $4 \mathrm{X}$ in the number of revertant colonies were observed in strain TA98 with activation at $3600 \mu \mathrm{g} /$ plate. A 2-3X increase was observed with activation in strain TA100 between $710 \mathrm{ug}$ and $3600 \mu \mathrm{g} / \mathrm{plate}$, and a 2-6X increase was observed with activation in strain TA1538 also between $720 \mu \mathrm{g}$ and $3600 \mu \mathrm{g} / \mathrm{plate}$.

Significant increases in numbers of revertant colonies were not observed in the test without S9 activation.

10. Burgess, L. E.; Meyers, A. I. J. Am. Chem. Soc. 1991, 113, 9858.

11. Wedler, C.; Schick, H.; Scharfenberg-Pfeiffer, D., Reck, G. Liebigs Ann. Chem. 1992, 29.

12. Heathcock, C. H.; Davidsen, S. K.; Hug, K. T.; Flippin, L. A. J. Org. Chem. 1986, 51, 3027.

13. Grieco, P. A.; Nunes, J. J.; Gaul, M. D. J. Am. Chem. Soc., 1990, 112, 4595.

14. Patricia Finnegan is gratefully acknowledged for help with the NOE experiment. 15. SC-52491 was tested versus five strains of Salmonella typhimurium (TA97, TA98, TA100, TA1535, and TA1538 in the presence and absence of rat liver homogenated metabolic activation system (S9) over SC-52491 concentrations ranging from 50 to 7500 $\mu \mathrm{g} / \mathrm{plate}$. There was no evidence of mutagenicity by SC-52491 in any of the strains tested. 